\title{
Shell occupation by the South Atlantic endemic hermit crab Loxopagurus loxochelis (Moreira, 1901) (Anomura: Diogenidae)
}

Israel Fernandes Frameschi, Luciana Segura de Andrade, Carlos Eduardo Rocha Duarte Alencar, Vívian Fransozo, Gustavo Monteiro Teixeira and Lissandra Corrêa Fernandes-Goés

(IFF, LSA) NEBECC, Núcleo de Estudos em Biologia, Ecologia e Cultivo de Crustáceos. Universidade Estadual Paulista - UNESP, Departamento de Zoologia, Instituto de Biociências Distrito de Rubião Junior, s/n, 18618-970, Botucatu, SP, Brazil. E-mail: frameschiif@ibb.unesp.br (CERDA) Grupo de Estudos de Ecologia e Fisiologia de Animais Aquáticos - GEEFAA, Universidade Federal do Rio Grande do Norte. Campus Universitário Lagoa Nova, 59072-970, Natal, RN, Brazil. (VF) Departamento de Ciências Naturais, Universidade Estadual do Sudoeste da Bahia. Estrada do Bem Querer, Km 04, 45031-900, Vitória da Conquista, BA, Brazil.

(GMT) Universidade Estadual de Londrina - UEL, Departamento de Biologia Animal e Vegetal. Rodovia Celso Garcia Cid, 86051980 Londrina, PR, Brazil.

(LCFG) Universidade Estadual do Piauí - UESPI. Av. Nossa Senhora de Fátima, s/n, Bairro de Fátima, 64202-220, Parnaíba, PI, Brazil.

\begin{abstract}
The evaluation of population characteristics, particularly those of endemic species, aids in population preservation and management. Hermit crabs present an innate behavior of occupying shells, which tends to individual needs and limits their distribution. This study characterized the pattern of occupation of gastropod shells by the hermit Loxopagurus loxochelis in three bays of the southwestern coast of Brazil. Monthly collections were made from January/1998 to December/1999 in the bays Ubatumirim (UBM), Ubatuba (UBA) and Mar Virado (MV) with a shrimping boat. Overall, ten species of gastropod shells were occupied by L. loxochelis. The shell of Olivancillaria urceus represented $66.8 \%$ of those occupied. Morphometric relationships demonstrated a differential occupation of the more abundant shells among demographic groups, where most of the males occupied $O$. urceus, non-ovigerous females occupied $O$. urceus and Buccinanops cochlidium, and ovigerous females occupied B. cochlidium and Stramonita haemastoma. Most of the individuals occupied the more abundant shells, considered adequate for the morphology of this hermit crab species. Thus, the studied bays seem to be stable and propitious environments for population perpetuation and the settlement of new individuals.
\end{abstract}

Key words: Gastropod shells, interspecific relationships, multivariate analysis, partial least square (PLS)

\section{INTRODUCTION}

The infraorder Anomura MacLeay, 1838 represents an important part of intertidal and benthic community of shallow regions, playing a remarkable role in trophic webs (Negreiros-Fransozo et al., 1997), which more than 100 species recorded for Brazilian coast (Melo, 1999). Among them, the superfamily Paguroidea includes all hermit crabs that occupy gastropod shells, in which families Paguridae and Diogenidae are included as well as more than 950 species from the whole world (McLaughlin et al., 2010). 
The shell provides protection to the non-calcified abdomen, making the hermit crab less susceptible to predator attack (Reese, 1968; Conover, 1978). Due to the abdomen morphology, hermit crabs are able to occupy and carry gastropod shells, and this feature is one of the main reasons for the evolutionary success of the group (Hazlett, 1981). Thereby, usually rare or absent shells are a determinant factor for the hermit crab distribution, consisting of a limiting factor for the individual and population growth (Kellogg, 1976).

The acquisition of shells starts from the megalope stage (post-larvae), characterized as innate behavior (Reese, 1963; Hazlett, 1971). According to individual needs, hermit crabs may find an adequate empty shell from locations in sites of gastropod predation (Mclean, 1973) or swap them during inter and intraspecific interaction (Rittschoff, 1980). Shell swap is mentioned in agonistic behavior among hermit crabs, not only on the establishment of dominant species, but mainly related to the competition for adequate shells (see more in Hazlett and Bossert, 1965; 1966; Hazlett, 1966; 1967; 1968; 1972). Hermit crabs display a peculiar behavior for inspection and choice of new shells, discriminating characteristics like weight, volume, shell aperture and wear (Resse, 1962; Conover, 1978). Univariate correlations between the measured variables are used to determine the relationship between the hermit crab and the occupied shell (Hazlett, 1981; Barnes, 1999; Arce and Alcaraz, 2009; Ismail, 2010). Authors like Kuris and Brody (1976), Caruso and Chemello (2009), and Ayres-Peres et al. (2012) employed the use of multivariate statistical tools, as the main compound analysis, with the aim to more securely appoint the factors that may bear high relevance for shell occupation, especially in natural environments.

The hermit crab Loxopagurus loxochelis (Moreira, 1901) is endemic of Southwestern Atlantic, being widely spread among the Brazilian state of Bahia to Argentina (Melo, 1999). The species biology has been studied continuously at the Brazilian coast (Mantelatto and Martinelli, 2001; Martinelli et al., 2002;
Mantelatto et al., 2004; Bertini et al., 2004; Biagi et al., 2006); however, due to the great extent of the Brazilian coast and endemism, it is necessary to evaluate the characteristics of distinct populations, as well as suitable gastropod shells used by different populations of $L$. loxochelis.

Therefore, the present study aims to outline the trend of gastropod shell occupation by demographic groups of $L$. loxochelis in three regions of the Northern coast of the state of São Paulo, through systematized collection and analysis, using the occupation percentage of different shells and multivariate analysis to pinpoint the morphometric variables of shells that are better related to the hermit crab morphology. Such information may provide a basis for the species' biology, especially with regards to its preservation.

\section{Material and Methods}

Animals were collected monthly from January 1998 to December 1999 in the bays Ubatumirim (UBM), Ubatuba (UBA) and Mar Virado (MV) (233'36”W/45¹1'32"S; $23^{\circ} 26^{\prime} 10$ " W / $45^{\circ} 011^{\prime} 36^{\prime \prime} \mathrm{S}$; $23^{\circ} 23^{\prime} 00^{\prime \prime} \mathrm{W} / 44^{\circ} 54^{\prime} 48^{\prime} \mathrm{S}$, respectively). Six transects were trawled over for each bay, delimited by a GPS (Global Position System). Collections were made with the aid of a shrimp fishing boat equipped with dual-rigged type nets with approximately $4.5 \mathrm{~m}$ openings and between-node distance of 20 and $15 \mathrm{~mm}$ of mesh size and cod end, respectively. Each transect comprised $2 \mathrm{Km}$ of extension for 30 minutes with an approximate area of $18,000 \mathrm{~m}^{2}$.

After each dragging, all the collected material was submitted to screening, frozen and transported to the laboratory, at which hermit crabs were identified according to Melo (1999), counted, removed manually from the shells, separated by gender according to gonopore position, weighed (wet weight, WW) on a precision scale (0.01g) and measured with use of a caliper rule $(0.10 \mathrm{~mm})$ in relation to cephalothorax shield length (CSL). Shells occupied by the hermit crab $L$. loxochelis were identified according to Rios 
(1994), dry weighed (SDW) and measured in relation to the shell aperture width (SAW). After 24 hours at $60^{\circ} \mathrm{C}$, shell internal volume (SIV) was measured by filling with water with a pipette, following Conover (1978).

Initially, morphometric data both of hermit crabs and shells were evaluated in comparison to the univariate normality through the Kolmogorov-Smirnov test. When there was no normality, data was transformed into logarithms and a variance analysis (ANOVA one way) was performed in order to verify the difference of each morphometric variable amongst occupied shell species, complemented by a Tukey test (Zar, 1996).

Multivariate analyses were performed to identify and evaluate the patterns of gastropod shell occupation by the hermit crab L. loxochelis, such as the principal component analysis (PCA), correspondence analysis (CA), multivariate analysis of variance (MANOVA) and partial least squares (PLS). All multivariate analyses were made through the $\mathrm{R}$ statistical computing software R ( $\mathrm{R}$ Development Core Team 2009). The use of each statistical package of the $\mathrm{R}$ software was performed separately in order to avoid possible mathematical algorithm conflicts of each function. The species of gastropods shells that featured an abundance equal to "one" were removed from the statistical analysis due to data inconsistency, and were considered rare species in the studied region. Initially data was tested regarding the multivariate normality by the symmetry and kurtosis test (Mardia, 1970; 1980) (with modifications suggested by Doornik and Hansen, 2008 - omnibus test). Furthermore, a Box's M test (Anderson, 1958) was performed to evaluate the equivalence (multivariate homogeneity) among covariance matrices of data, with Monte Carlo permutations to estimate the significance value of this test.

A PCA was conducted to verify which species of gastropod shells are more explanatory during the selection of demographic groups (males, females, ovigerous females) of $L$. loxochelis. Variations higher than 0.7 and the principal component that explained more than $80 \%$ of data variation were considered significant. PCA was conducted by "vegan" package (Oksanen, 2011; vegan.r-forge.rproject.org).

Data related to abundance of each demographic group, for each species of shell occupied, were organized in a two factors contingence table in order to conduct a Correspondence Analysis (CA). During the CA, observed associations of both variables (demographic group and shell species) were summarized by the frequency of each table cell, and then positioned in a geometric dimensional space, since the positions of each line and column were consistent with the associations of the table. The axes that corresponded to a cumulative variation higher than $80 \%$ were considered significant. In addition, graphic points related to the shell species were arranged according to their abundance in the contingency table, creating a view of association/abundance of each shell species within demographic groups. A CA was performed through the "CA" routine of the "CA" package (Grenacre, 1993; Nenadic and Greenacre, 2007). Then, a MANOVA was performed with involvement of data regarding shell abundance by the factors (1) demographic groups and (2) collection locality, to investigate the difference of means of abundance.

The PLS was used for analysis of morphometric data from occupied shells and their respective resident hermit crab. This analysis consists of a recent technique that generalizes and combines characteristics of a principal component analysis and multiple regression. This technique has been used to forecast a set of dependent variables (morphometric data matrix of hermit crabs) from a set of independent variables (morphometric data matrix of shells) (see more in Abdi, 2007). This technique was built over a robust mathematic framework and details may be seen in Höskuldsson (1988) and Haenlein and Kaplan (2004). The variable in importance projection (VIP), coefficients and weight of morphometric variables of shells in relation to the hermit crabs were analyzed among demographic groups of hermit crabs from collection locations and, in general combining data from all bays. 
The VIP consists of a statistic generated by the PLS, which shows the contribution of the independent variable to the model. Based on Wold (1995), VIP values higher than 1 were considered high variable contribution to the model, VIP between 1 and 0.8 , relevant contribution, and VIP lower than 0.8 , not relevant contribution. Independent variable weights were used to determine their influence on the projection (VIP). As there is not a statistic PLS test to demonstrate significant differences among VIPs, the values from variable weights were also analyzed to facilitate the interpretation of VIP values. PLS regression was performed through the "plsreg2" routine of "plspm" package (Sanchez and Trinchera, 2012; plsmodeling.com).

\section{Results}

Overall, 883 individuals of $L$. loxochelis were captured in the three bays (Tab. 1). In UBM and UBA eight species of shells were occupied, while in MV six species used by hermit crabs were recorded, with a total of ten species being occupied by $L$. loxochelis. In all the localities the most occupied gastropod shell was Olivancillaria urceus (Röding, 1798) (Fig. 1a), followed by Buccinanops cochlidium (Dillwyn, 1817) (Fig. 1b) and Stramonita haemastoma (Linnaeus, 1767) (Fig. 1c) (Tab. 1). Animals were divided into 12 size classes, with $0.6 \mathrm{~mm}$ amplitude, from a minimum size of $2.5 \mathrm{~mm}$ of CSL. The relative frequency distribution of individuals in size classes presented normal patterns, with unimodal distribution (UBM, $\mathrm{KS}=0.058, \mathrm{p}=0.20$; UBA, $\mathrm{KS}=0.601, \mathrm{p}=$ 0.10; and $\mathrm{MV}, \mathrm{KS}=0.078, \mathrm{p}=0.10$ ) (Fig. 2). A significant difference was observed between the mean dry weight (ANOVA; $\mathrm{F}=55.48, \mathrm{p}<$ $0.01)$ and aperture width $(\mathrm{F}=21.35, \mathrm{p}<0.01)$, and the $O$. urceus presented the highest weight (Tukey; $\mathrm{p}<0.01$ ), and also the lowest aperture width among the most occupied species ( $p$ $<0.01$ ). As for the shells internal volume of occupied, B. cochlidium was significantly the highest $(\mathrm{p}<0.01)$ (Tab. 2).

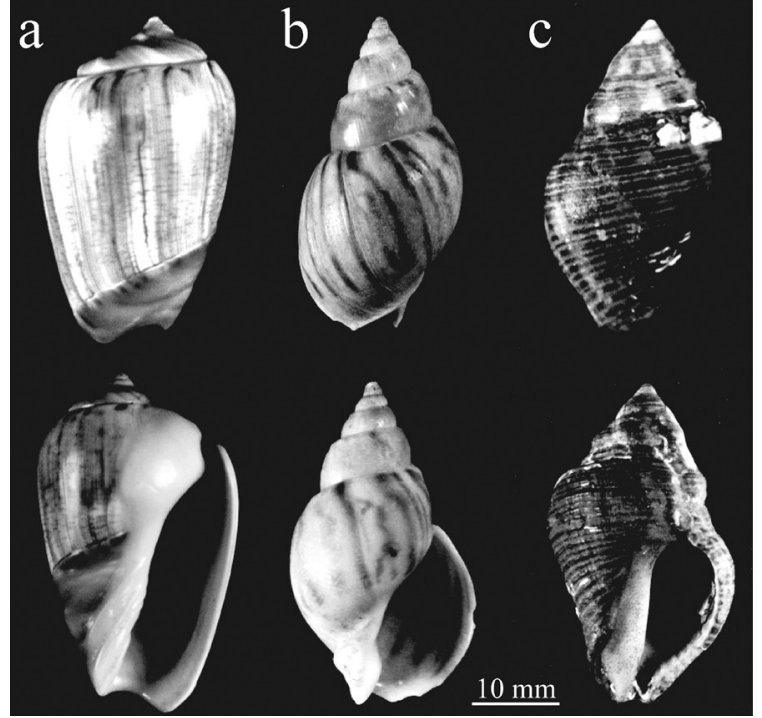

Figure 1. Most frequently used species of gastropod's shells occupied by Loxopagurus loxochelis in the subtropical region of Brazil. (a) Olivancillaria urceus. (b) Buccinanops cochlidium. (c) Stramonita haemastoma.

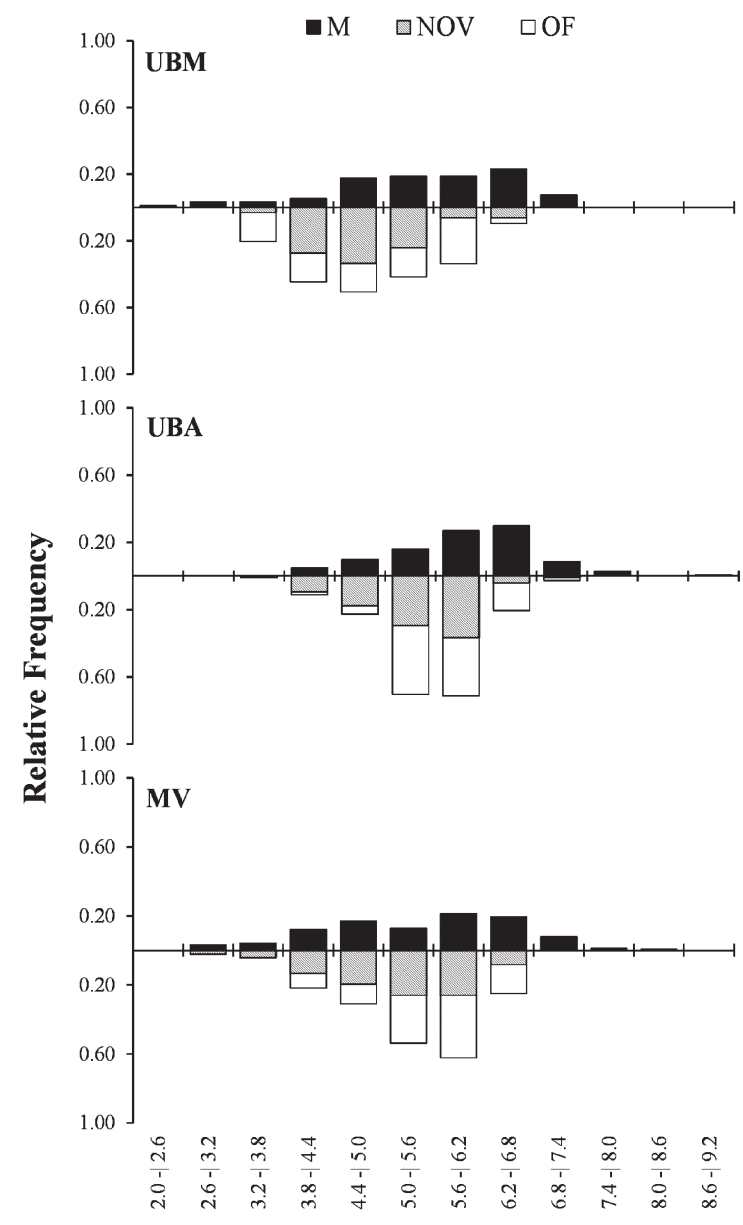

Cephalothoracic shield length $(\mathrm{mm})$

Figure 2. Relative frequency distribution for each group of interest of individuals collected in the subtropical region of Brazil. $(\mathrm{M}=$ males; $\mathrm{NOF}=$ non-ovigerous females; $\mathrm{OF}=$ ovigerous females). 
Table 1. Percentage of gastropod shell species occupation by L. loxochelis in the three bays of Ubatuba region ( $\mathrm{SP})$. ( $\mathrm{N}=$ number of individuals; $\mathrm{M}=$ males; $\mathrm{NOF}=$ non-ovigerous females; $\mathrm{OF}$ = ovigerous females).

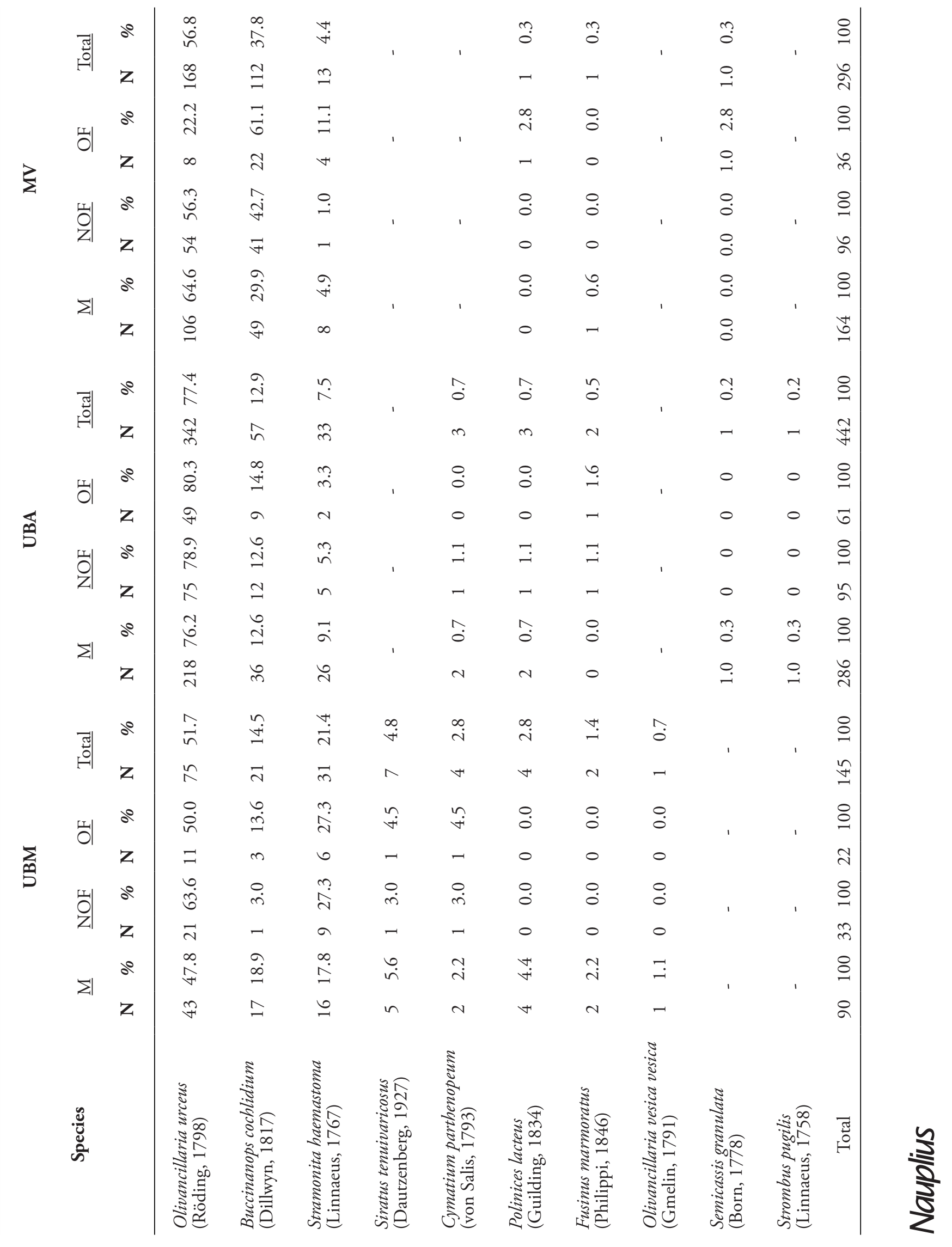


Table 2. Characterization of 883 gastropod shells occupied by L. loxochelis species from three bays, and results of ANOVA test, in which different letters differ significantly ( $\mathrm{OP}=$ occurrence percentage).

\begin{tabular}{|c|c|c|c|c|c|c|c|}
\hline \multirow[b]{2}{*}{ Gastropod species } & \multirow[b]{2}{*}{$\mathbf{N}$} & \multicolumn{2}{|c|}{ Weight } & \multicolumn{2}{|c|}{ Aperture Width } & Internal Volume & \multirow[b]{2}{*}{$\begin{array}{l}\text { OP } \\
(\%) \\
\end{array}$} \\
\hline & & \multicolumn{2}{|c|}{ Mean \pm SD } & \multicolumn{2}{|c|}{ Mean \pm SD } & Mean \pm SD & \\
\hline $\begin{array}{l}\text { Olivancillaria urceus } \\
\text { (Röding, 1798) }\end{array}$ & 585 & $\begin{array}{c}1.06 \\
8.75\end{array}$ & $\begin{array}{l}36.08 \\
.26 \mathrm{a}\end{array}$ & $\begin{array}{l}3.1 \\
6.67\end{array}$ & $\begin{array}{l}13.4 \\
39 \mathbf{a}\end{array}$ & $\begin{array}{l}0.3 \quad 6.5 \\
2.84 \pm 1.39 \mathbf{a}\end{array}$ & 66.25 \\
\hline $\begin{array}{l}\text { Buccinanops cochlidium } \\
\text { (Dillwyn, 1817) }\end{array}$ & 190 & $\begin{array}{l}0.62 \\
4.15\end{array}$ & $\begin{array}{l}12.83 \\
.07 \mathbf{b}\end{array}$ & $\begin{array}{l}4.2 \\
7.88\end{array}$ & $\begin{array}{r}14.7 \\
72 \mathbf{b}\end{array}$ & $\begin{array}{l}0.4 \quad 10 \\
3.67 \pm 1.41 \quad \mathbf{b c}\end{array}$ & 21.52 \\
\hline $\begin{array}{l}\text { Stramonita haemastoma } \\
\text { (Linnaeus, 1767) }\end{array}$ & 77 & $\begin{array}{c}0.66 \\
4.75\end{array}$ & $\begin{array}{l}12.95 \\
.78 \mathbf{b}\end{array}$ & $\begin{array}{l}3.2 \\
8.35\end{array}$ & $\begin{array}{l}15.2 \\
63 \mathbf{b}\end{array}$ & $\begin{array}{l}0.2 \quad 9 \\
2.39 \pm 1.78 \quad \mathbf{b}\end{array}$ & 8.72 \\
\hline $\begin{array}{l}\text { Polinices lacteus } \\
\text { (Guilding, 1834) }\end{array}$ & 8 & $\begin{array}{l}0.7 \\
3.08\end{array}$ & $\begin{array}{r}4.77 \\
.64 \mathrm{~b}\end{array}$ & $\begin{array}{l}6.3 \\
9.45\end{array}$ & $\begin{array}{r}11.3 \\
75 \mathbf{b}\end{array}$ & $\begin{array}{lr}0.6 & 2.5 \\
1.27 \pm 0.75 \text { b }\end{array}$ & 0.91 \\
\hline $\begin{array}{l}\text { Cymatium parthenopeum } \\
\text { (von Salis, 1793) }\end{array}$ & 7 & $\begin{array}{c}2.12 \\
4.13\end{array}$ & $\begin{array}{r}6.31 \\
.61 \mathbf{b}\end{array}$ & $\begin{array}{l}7.2 \\
8.51\end{array}$ & $\begin{array}{r}9.5 \\
82 \mathbf{b}\end{array}$ & $\begin{array}{c}1.1 \quad 4.3 \\
2.83 \pm 1.25 \text { ac }\end{array}$ & 0.79 \\
\hline $\begin{array}{l}\text { Siratus tenuivaricosus } \\
\text { (Dautzenberg, 1927) }\end{array}$ & 7 & $\begin{array}{l}1.8 \\
4.50=\end{array}$ & $\begin{array}{r}9.59 \\
.62 \mathrm{~b}\end{array}$ & $\begin{array}{c}5.7 \\
7.80\end{array}$ & $\begin{array}{l}9.7 \\
0 \mathbf{a b}\end{array}$ & $\begin{array}{lr}0.4 & 4.4 \\
1.92 \pm 1.53 \mathbf{~ b}\end{array}$ & 0.79 \\
\hline $\begin{array}{l}\text { Fusinus marmoratus } \\
\text { (Philippi, 1846) }\end{array}$ & 5 & $\begin{array}{l}0.79 \\
3.88\end{array}$ & $\begin{array}{r}5.97 \\
.94 \mathbf{b}\end{array}$ & $\begin{array}{l}4.7 \\
6.68\end{array}$ & $\begin{array}{r}7.6 \\
6 \mathbf{a b}\end{array}$ & $\begin{array}{cc}0.5 & 2.5 \\
1.70 \pm 1.06 \quad \mathbf{a b c}\end{array}$ & 0.57 \\
\hline $\begin{array}{l}\text { Semicassis granulata } \\
\text { (Born, 1778) }\end{array}$ & 2 & $\begin{array}{r}2.44 \\
4.77\end{array}$ & $\begin{array}{l}7.09 \\
3.29\end{array}$ & & $\begin{array}{l}11.1 \\
.62\end{array}$ & $\begin{array}{l}3.1 \quad 3.1 \\
3.10 \pm 1.39\end{array}$ & 0.23 \\
\hline $\begin{array}{l}\text { Strombus pugilis } \\
\text { (Linnaeus, 1768) }\end{array}$ & 1 & & & & & 5 & 0.11 \\
\hline $\begin{array}{l}\text { Olivancillaria vesica vesica } \\
\text { (Gmelin, 1791) }\end{array}$ & 1 & & & & & 1.8 & 0.11 \\
\hline
\end{tabular}

The PCA evidenced the shells of $O$. urceus, $B$. cochlidium and $S$. haemastoma as the most representative for the pattern of shell occupancy of L. loxochelis (Tab. 3). From these results, a correspondence analysis was performed, evidencing greater utilization of males for shells of $O$. urceus, while nonovigerous females occupied $O$. urceus and $B$. cochlidium more often. Ovigerous females used B. cochlidium and S. haemastoma (Fig. 3). The results obtained by the MANOVA to evaluate the differences of the mean abundance of choices, by demographic groups and localities, indicated that there was difference only among locations (Tab. 4).

The variance accumulated in each PLS essay was over $80 \%$ for the two initial factors, except for trials on ovigerous females

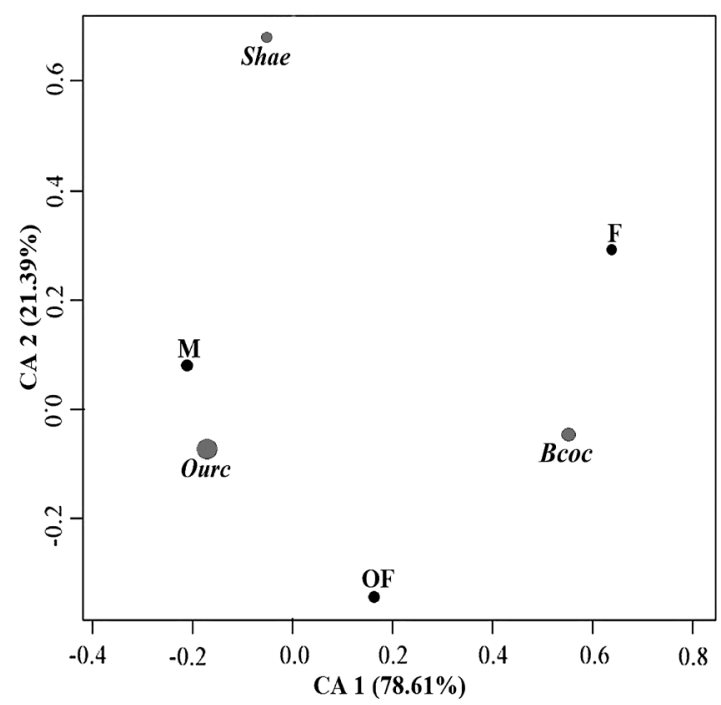

Figure 3. Correspondence analysis of $O$. urceus (Ourc), B. cochlidium (Bcoc) and S. haemastoma (Shae) shell abundance occupied by males $(\mathrm{M})$, non-ovigerous females $(\mathrm{F})$ and ovigerous females (OF) of $L$. loxochelis captured in the subtropical region of Brazil. 
group by location. Probably this was due to the low number of specimens collected in this condition. However, the analysis of PLS sample residues for each factor did not evidence outliers, confirming matrices of original data for PLS analysis.

Results of shell weight for shell morphometric variables occupied by males were close to the SAW and SIV variables, mainly in the first factor, confirming these variables as the most influential in the two linear compositions of variables from the two data sets of PLS factors. Trials by localities followed some pattern. The same relationship of higher values and proximity of weight variables also was observed for ovigerous and non-ovigerous females. There was no weight close the origin, indicating that variables contributed substantially to the predictive capacity of the model. Thereby, such results indicated that SAW and SIV had the same explanatory weight in PLS factors (Tab. 5).
Results of the general trials indicated that males presented a pattern of shell choice that considered the three measured variables (SDW, SAW, SIV). Volume and aperture width are the most important variables (VIP $>1$ ) and weight presents minor importance (VIP $>0.8$ ). For ovigerous and non-ovigerous females, SAW and SIV measurements presented a higher contribution importance in shell choice (VIP > 1 ), while SDW was not determinant in relation to this choice (VIP < 0.8). Comparing results of VIPs among demographic groups, it was observed that males presented higher values for SDW (0.81) and lower for SAW (1.1) and SIV (1.06), while ovigerous and non-ovigerous females presented an inverse pattern with lower values for SDW (0.67 and 0.72, respectively) and SIV (1.1 and 1.12, respectively). The same patterns observed on overall trials were detected on the trials per collection location (UBM, UBA and MV), except for nonovigerous females from UBM, in which three

Table 3. Statistical abstract of Principal Component Analysis (PCA), in bold the values of the principal L. loxochelis species of occupied shells.

\begin{tabular}{lccc}
\hline & PC1 & PC2 & PC3 \\
\hline Standard deviation & 159.798 & 4.321 & 0.000 \\
Proportion of Variance & 0.999 & 0.001 & 0.000 \\
Cumulative Proportion & 0.999 & 100.000 & 1.000 \\
O. urceus & $\mathbf{- 0 . 9 6 7}$ & -0.089 & 0.208 \\
B. cochlidium & -0.219 & -0.195 & $\mathbf{- 0 . 8 1 6}$ \\
S. haemastoma & -0.130 & $\mathbf{0 . 9 4 8}$ & -0.219 \\
P. lacteus & -0.017 & 0.176 & 0.478 \\
C. parthenopeum & -0.010 & -0.024 & -0.041 \\
S. tenuivaricosus & -0.014 & 0.141 & -0.102 \\
F. marmoratus & -0.007 & 0.070 & -0.051 \\
\hline
\end{tabular}

Table 4. Multivariate Analysis of Variance (MANOVA) of the abundance of shells occupied by Loxopagurus loxochelis demographic groups and sampled locality. Wilk's = Wilk lambda, Pillai's = Pillai trace.

\begin{tabular}{lcccccc}
\hline & Test & Value & F & $\begin{array}{c}\text { Effect } \\
\text { df }\end{array}$ & $\begin{array}{c}\text { Error } \\
\text { df }\end{array}$ & $P$ \\
\hline Intercept & Wilks & 0.546656 & 6.910864 & 3 & 25 & 0.001 \\
\multirow{3}{*}{ Locality } & Pillai's & 0.453344 & 6.910864 & 3 & 25 & 0.001 \\
& Wilks & 0.545677 & 2.947755 & 6 & 50 & 0.015 \\
Sex & Pillai's & 0.499887 & 2.888016 & 6 & 52 & 0.016 \\
\multirow{3}{*}{ Locality*Sex } & Wilks & 0.768503 & 1.172629 & 6 & 50 & 0.335 \\
& Pillai's & 0.232727 & 1.14129 & 6 & 52 & 0.351 \\
& Wilks & 0.839168 & 0.379342 & 12 & 66 & 0.966 \\
& Pillai's & 0.166255 & 0.39602 & 12 & 81 & 0.961 \\
\hline
\end{tabular}


Table 5. L. loxochelis. Results for each location and overall Partial Least Square (PLS) of males, non-ovigerous females and ovigerous females, for the morphometric data of L. loxochelis (WT = Weight; CSL = cephalothoracic shield length) and morphometric data of gastropods shells (SDW = shell dry weight; SAW = shell apperture width; SIV = shell internal volume) most significant according to PCA. WW and CSL - coefficients of the morphometric shell variables for each morphometric hermit crab variable; VIP = Variable Importance Projection to the first factor of the PLS; PLS1w, PLS2w - weight of predictor variables for the PLS factors. VIP > 0.8 significant contribution of the variable; VIP $>1$ high contribution of the variable.

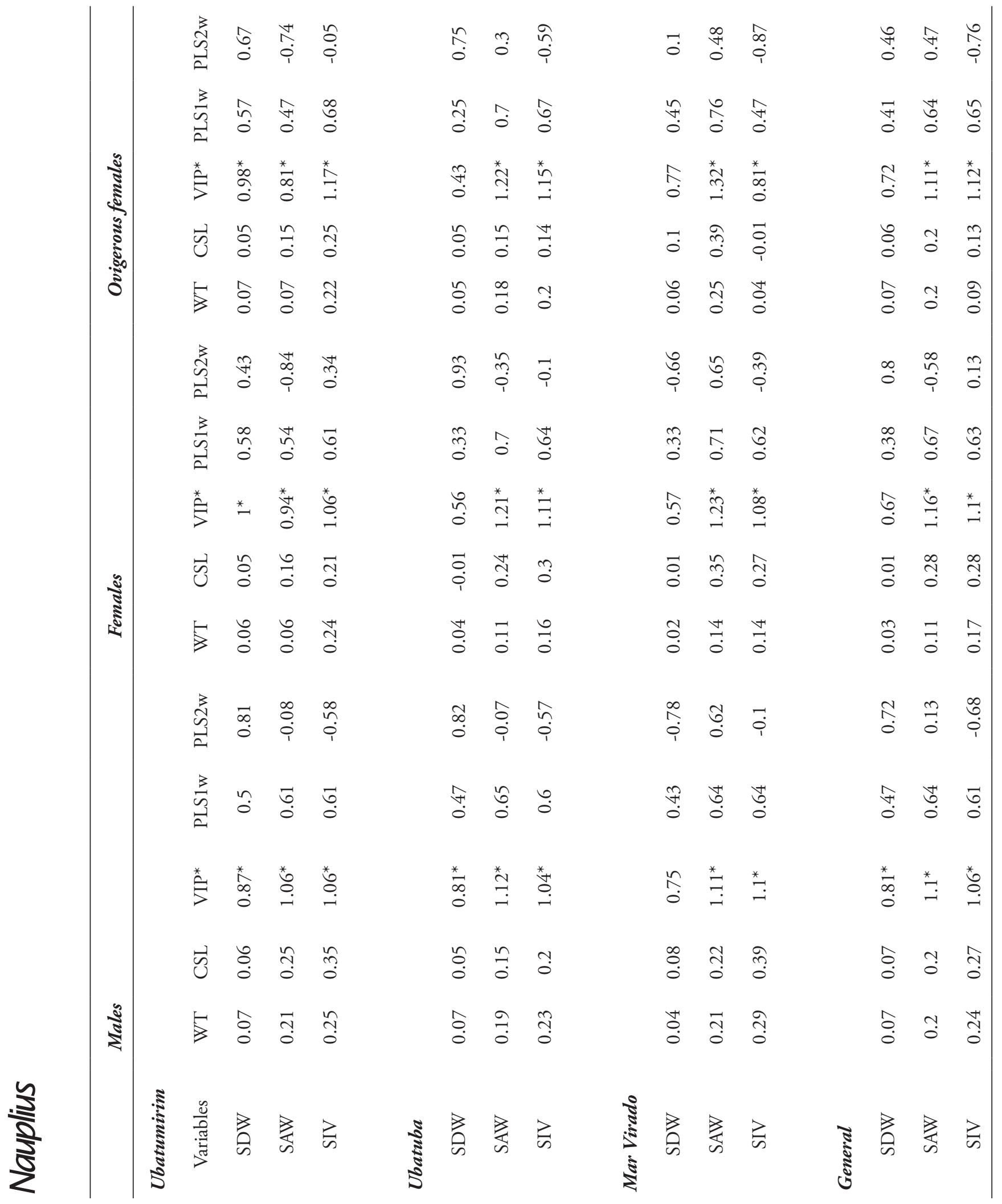


morphometric variables of shells presented high values of importance (VIP) (Tab. 5). It is noteworthy that in this bay only one hermit crab was collected occupying the shell of $B$. gradatus. All linear compositions of first factor values for each morphometric matrix (hermit crab and shell) presented a correlation higher than 0.7 (representing association strength between variables).

\section{Discussion}

The shell of $O$. urceus is the most occupied by hermit crab species of unconsolidated substrate in the subtropical region of the Brazilian coast (Ayres-Peres et al., 2008; Fransozo et al., 2008). As well as the hermit crab Dardanus insignis (Saussure, 1858) and Isocheles sawayai (Forest and Saint Laurent, 1968) (Miranda et al., 2006; Fantucci et al., 2008; respectively), L. loxochelis mostly occupied the shell of $O$. urceus in the three bays. Overall, the hermit crab approached by the current study occupied ten species of shells, more species when in comparison to the study made by Martinelli and Mantelatto (1999) in the same region. However, in the study conducted by AyresPeres et al. (2012) in the two regions, the hermit crab L. loxochelis occupied shells of 15 gastropod species. The previous records listed the use of many species of gastropod shells by L. loxochelis, with $O$. urceus and B. cochlidium as the most occupied, corroborating the occupational trends demonstrated herein, and defining the occupational pattern of $L$. loxochelis as specialist. According Hazlett et al. (2005), even with a large number of shells, some species of hermit crabs choose to use of species-specific shells when these appear to be the more favorable to morphology and lifestyle. Besides $O$. urceus, the shells of $B$. cochlidium and S. haemastoma also presented relevant abundances in all the demographic groups, where the $O$. urceus and $B$. cochlidium were the most representative species.

The availability of the aforementioned shell species may have been determined by gastropod death and shell transportation by marine currents, or by biotic transport as mentioned by Asakura and Kikuchi (1984). The use of shells that are not available in the environment where hermit crabs were collected is attributed to several factors, like individual migration which carries them (Lancaster, 1988); shells buried in the substrate (Kellogg, 1976); anthropic influence (e.g. Fishers); and transport from one area to other by influence of marine currents (Vance, 1972). In fact, this last factor is decisive for the use of the $S$. haemastoma shell by $L$. loxochelis, since this gastropod is typical of intertidal regions, with consolidated substrate (Limaverde et al., 2007). According to Mantelatto and Garcia (2000), S. haemastoma is the most preferred shell of the diogenid hermit crab typical of intertidal regions, Calcinus tibicen (Herbst, 1791). The same authors highlighted the great abundance of this gastropod in a sublittoral of unconsolidated substrate, which justifies the number of this species' shells being used both by L. loxochelis (Martinelli and Mantelatto, 1999 and present work), and I. sawayai (Fantucci et al., 2008), that inhabits shallow regions, next to this coast (see Fransozo et al., 2012). Interspecific competition has huge influence in the pattern of shell occupation. This assumption is based in the differential spatial distribution of the species, where $L$. loxochelis coexists with other hermit crabs, like D. insignis, Pagurus exilis (Benedict, 1892) and mainly $I$. sawayai, which were frequently recorded within the range of five meters deep on the Northern coastline of São Paulo (Fransozo et al., 2008).

Studying the pattern of shell use by I. sawayai, Pinheiro et al. (1993) records by means of the relation between the shell aperture width and cephalothoracic shield length, that similar size hermit crabs may occupy different sized shells, corroborating the high occupation of three different species (O. urceus, B. cochlidium and S. haemastoma) by all demographic groups of $L$. loxochelis. According to Blackstone (1985), Pagurus longicarpus (Say, 1817) is able to discriminate differences of weight and internal volume of shells that present the same aperture width. 
These different morphological trends of shells regarding weight and volume influence their suitability both for growth and reproduction. In the present study, was observed that internal volume was a determinant factor in shell choice by $L$. loxochelis, on the other hand, Hazlett (1970), working with Pagurus bernhardus (L.), and Conover (1976), working with Pagurus pollicaris Say and Pagurus longicarpus Say, claim the weight was the most important condition only when larger shells were available.

Similar results were described by Bertini and Fransozo (2000) for the hermit crab Petrochirus diogenes (Linnaeus, 1758), which observed that the best relationship between hermit crab measurements and shell weight were directed towards species of larger shells, which were the most occupied: Tonna galea (Mörch, 1877), Zidona dufresnei (Donovan, 1823), and shorter species of, like the Strombus pugilis (Linnaeus, 1758), were only occupied due to lack of others. In the study made with $L$. loxochelis by Martinelli and Mantelatto (1999) and Ayres-Peres et al. (2012), morphometric relations evidenced that $O$. urceus and $B$. cochlidium presented the highest values of correlation coefficient for all relationships between the animal (CSL and WW) and the shell (SAW and SDW).

Despite all its historical importance and application in biology and ecology, linear regression does not analyze the correlation of morphometric variables in a multivariate analysis. An alternative already documented that generated trustful results is Partial Least Square (PLS) (Carrascal et al., 2009) which analyzes the weight and importance of each variable from a multivariate set. From PLS results it was possible to identify SAW and SIV as shell variables are the most active towards shell choice by all demographic groups of L. loxochelis. Secondarily, the variable SDW also influences shell choice for males. In a previous study with this species Martinelli and Mantelatto (1999) described morphometric relationships with shell weight (SDW) as relevant as shell aperture (SAW). However, Ayres-Peres et al. (2012) appointed the internal volume as the most important variable in the decision of choosing the shell in L. loxochelis, as found in this study. It is important to highlight that those authors used principally linear regressions to describe the choice patterns. In addition, Lively (1988) in a laboratory study manipulating the shell mass, discovered that the volume was more important than weight in the shell choice by hermit crabs, corroborating the results for $L$. loxochelis, obtained in this study.

Other studies related a trend of $L$. loxochelis ovigerous females on shell occupation of the gastropod B. cochlidium (Martinelli and Mantelatto, 1999; Torati and Mantelatto, 2008; Ayres-Peres et al., 2012). In the present study, L. loxochelis ovigerous females followed this pattern, occupying shells with greater volume and aperture width ( $B$. cochlidium and $S$. hameastoma, respectively). These may be the main factors that guide the occupation of this demographic group (Fotheringham, 1980; Hazlett, 1981; Garcia and Mantelatto, 2001; Mantelatto and Dominciano, 2002; Mantelatto et al., 2002; Hazlett et al., 2005). The greater internal volume results in the increase of functional capacity for reproductive processes, as fecundity, allowing achieving the potential growth, and providing more protection to the eggs (Mantelatto and Garcia, 1999; Mantelatto and Dominciano, 2002) and against predators (Reese, 1969; Markham, 1968; Vance, 1972; Mantelatto and Martinelli, 2002).

Most of the hermit crab species present males larger than females (Bertness, 1981; Wada, 2001; Mantelatto and Martinelli, 2001; Litulo, 2005). Males of larger dimensions are generally more prone to "win" intraspecific interactions with smaller males, allowing great access (Wada et al., 1996; 1999) and choice by females, as well as greater copulation success (see more in Hazlett, 1989; Hazlett and Baron, 1989). The L. loxochelis males occupied the most available shell of the region (O. urceus), larger and heavier than those occupied by non ovigerous females (B. cochlidium). This occupational trend is caused by the differential 
energetic balance presented by groups of sexual genus. According to Abrams (1988), females deviate part of the energy for gonad development, while males invest in growth to ensure copulation when there are other males vying for the same female. The growth spends a greater cost of energy and time, since to grow they need, besides the usual metabolic processes, to constantly change their shells (Hazlett, 1981; Briffa and Elwood, 2004; Gherardi, 2006).

The analysis made in the present study allows concluding that through morphometric relations between variables of the hermit crabs and their shells, there is an occupational trend adequate to weight, size and demographic group of individuals. Thereby, the presence of L. loxochelis in the São Paulo littoral is ensured by the diversity and availability of gastropod shells adequate to the species. Its presence may be molded by intra and interspecific competition. In this case, it occurs mainly due to the acquisition of shells, and secondly due to the short size achieved by $L$. loxochelis, which competes with adults of other smaller species, like $P$. exilis and I. sawayai, and juveniles of species that achieve larger sizes, like $D$. insignis and $P$. diogenes.

Acknowledgements - We are grateful to FAPESP for financial support (97/12107-0), to NEBECC members for their help during laboratory and hard fieldwork and anonymous reviewers for the comments. This study was performed according to state and federal laws concerning wild-animal sampling.

\section{REFERENCES}

Abdi, H. 2007. Partial least square regression (PLS regression). p. 740-744. In: N.J. Salkind (ed.), Encyclopedia of Measurement and Statistics. Thousand Oaks (CA), Sage.

Abrams, P.A. 1988. Sexual difference in resource use in hermit crabs; consequences and causes. p. 283-296. In G. Chelazzi, and M. Vannini, (eds.). Behavioral adaptations to intertidal life. Plenum Press, New York.

Anderson, T.W. 1958. An Introduction to Multivariate Statistical Analysis, John Wiley and Sons, Inc., New York, 374p.

Arce, E. and Alcaraz, G. 2011. Shell use by the hermit crab Calcinus californiensis at different levels of the intertidal zone. Scientia Marina, 75(1): 121-128.

Asakura, A. and Kikuchi, T. 1984. Population ecology of the sand dwelling hermit crab Diogenes nitidimanus, Terao. 2. Migration and life history. Publication of
Amakusa Marine Biology Laboratory, 7: 109-123.

Ayres-Peres, L.; Sokolowicz, C.C.; Kotzian, C.B.; Rieger, P.J. and Santos, S. 2008. Ocupação de conchas de gastrópodes por ermitóes (Decapoda, Anomura) no litoral de Rio Grande, Rio Grande do Sul, Brasil. Iheringia, Série Zoologia, 98(2): 218-224.

Ayres-Peres, L.; Quadros, A.F. and Mantelatto, F.L. 2012. Comparative analysis of shell occupation by two southern populations of the hermit crab Loxopagurus loxochelis (Decapoda, Diogenidae). Brazilian Journal of Oceanography, 60(3): 299-310.

Barnes, D.K.A. 1999. Ecology of tropical hermit crabs at Quirimba Island, Mozambique: shell characteristics and utilization. Marine Ecology Progress Series, 18: 241-251.

Bartness, M.D. 1981. The influence of shell-type on hermit crab growth rate and clutch size. Crustaceana, 40: 197-205.

Bertini, G. and Fransozo, A. 2000. Patterns of utilization in Petrochirus diogenes (Decapoda, Anomura, Diogenidae) in the Ubatuba region, São Paulo, Brazil. Journal of Crustacean Biology, 20(3): 468-473.

Bertini, G.; Fransozo, A. and Braga, A.A. 2004. Ecological distribution and reproductive period of the hermit crab Loxopagurus loxochelis (Anomura, Diogenidae) on the northern coast of São Paulo State, Brazil. Journal of Natural History, 38(18): 2331-2344.

Biagi, R.; Meireles, A.L.; Scelzo, M.A. and Mantelatto, F.L. 2006. Comparative study of shell choice by the southern endemic hermit crab Loxopagurus loxochelis from Brazil and Argentina. Revista Chilena de Historia Natural, 79(4): 481-487.

Blackstone, N.W. 1985. The effects of shell size and shape on growth and form in the hermit crab Pagurus longicarpus. The Biological Bulletin, 168: 75-90.

Briffa, M. and Elwood, R.W. 2004. Use of energy reserves in fighting hermit crabs. Proceedings of the Royal Society London Biological Science, 271: 373379.

Carrascal, L.M.; Galvan, I. and Gordo, O. 2009. Partial least squares regression as an alternative to current regression methods used in ecology. Oikos, 118: 681-690.

Caruso, T. and Chemello, R. 2009. The size and shape of shells used by hermit crabs: A multivariate analysis of Clibanarius erythropus. Acta Oecologica, 35: 349354.

Conover, M.R. 1978. The importance of various shell characteristics to the shell-selection behavior of the hermit crabs. Journal of Experimental Marine Biology and Ecology, 32: 131-142.

Conover, M.R. 1976. The influence of some symbionts on the shell selection behavior of the hermit crabs, Pagurus pollicaris and Pagurus longicarpus. Animal Behaviour, 24: 191-194.

Doornik, J.A. and Hansen, H. 2008. An Omnibus Test for Univariate and Multivariate Normality. Oxford Bulletin of Economics and Statistics, 70: 927-939.

Fantucci, M.Z.; Biagi, R. and Mantelatto, F.L. 2008. Shell occupation by the endemic western Atlantic hermit crab Isocheles sawayai (Diogenidae) from Caraguatatuba, Brazil. Brazilian Journal of Biology, 68(4): 859-867.

Fotheringham, N. 1980. Effects of shell utilization on reproductive patterns in tropical hermit crabs. 
Marine Biology, 55: 287-293.

Fransozo, A.; Bertini, G.; Braga, A.A. and NegreirosFransozo, M.L. 2008. Ecological aspects of hermit crabs (Crustacea, Anomura, Paguroidea) off the northern coast of São Paulo State, Brazil. Aquatic Ecology, 42: 437-448.

Fransozo, A.; Furlan, M.; Fransozo, V.; Bertini, G.; Costa, R.C. and Fernandes-Góes, L.C. 2012. Diversity of decapod crustaceans at the interface of unconsolidated seabed areas and rocky shores in tropical/subtropical Brazil. African Journal of Marine Science, 34(3): 361-371.

Garcia, R.B. and Mantelatto, F.L. 2001. Shell selection by the tropical hermit crab Calcinus tibicen (Herbst, 1791) (Anomura, Diogenidae) from Southern Brazil. Journal of Experimental Marine Biology and Ecology, 265: 1-14.

Gherardi, F. 2006. Fighting behavior in hermit crabs: the combined effect of resource-holding potential and resource value in Pagurus longicarpus. Behavioral Ecology and Sociobiology, 59: 500-510.

Greenacre, M.J. 1993. Biplots in Correspondence Analysis. Journal of Applied Statistics, 20: 251-269.

Haenlein, M. and Kaplan, A.M. 2004. A beginner's guide to partial least squares analysis. Understanding Statistics, 3(4): 283-297.

Hazlett, B.A. 1966. Social behavior of the Paguridae and Diogenidae of Curaçao. Studies Fauna of Curaçao, 23: 1-143.

Hazlett, B.A. 1967. Interspecific shell fighting between Pagurus bernhardus and Pagurus cuanensis (Decapoda, Paguridae). Sarsia, 29: 215-220.

Hazlett, B.A. 1968. Size relationships and aggressive behavior in the hermit crab, Clibanarius vittatus. Zeitschrift für Tierpsychologie, 25: 608-614.

Hazlett, B.A. 1970. Tactile stimuli in the social behavior of Pagurus bernhardus (Decapoda, Paguridae). Behaviour, 36:20-47.

Hazlett, B.A. 1972. Ritualization in marine Crustacea. p. 97-125. In: Wim, H. A. and Olla, B. (eds.) Behaviour of marine animals. Vol. 1, New York, Plenum Press.

Hazlett, B.A. 1981. The behavioural ecology of hermit crabs. Annual Review of Ecology and Systematics, 12:1-22.

Hazlett, B.A. 1989. Mating success of male hermit crabs in shell generalist and shell specialist species. Behavioral Ecology and Sociobiology, 25: 119-128.

Hazlett, B.A. and Baron, L.C. 1989. Influence of shells on mating behavior in the hermit crab Calcinus tibicen. Behaviour Ecology and Sociobiology, 24: 369376.

Hazlett, B.A. and Bossert, W.H. 1965. A statistical analysis of the aggressive communications systems of some hermit crabs. Animal Behaviour, 13: $357-$ 372.

Hazlett, B.A. and Bossert, W.H. 1966. Additional observations on the communications systems of hermit crabs. Animal Behavior, 14: 546-549.

Hazlett, B.A.; Rittschof, D. and Bach, C.E. 2005. The effects of size and coil orientation on reproduction in female hermit crabs, Clibanarius vittatus. Journal of Experimental Marine Biology and Ecology, 323: 9399.

Höskuldsson, A. 1988. PLS regression methods. Journal of Chemometrics, 2(3): 211-228.

Ismail, T.G.E.K. 2010. Distribution and shell selection by two hermit crabs in different habitats on Egyptian
Red Sea Coast. Acta Oecologica, 36: 314-324.

Kellogg, C.W. 1976. Gastropod shells: a potentially limiting resource for hermit crabs. Journal of Experimental Marine Biology and Ecology, 22: 101111.

Kuris, A.M. and Brody, M.S. 1976. Use of principal components analysis to describe the snail shell resource for hermit crabs. Journal of Experimental Marine Biology and Ecology, 22: 69-77.

Lancaster, I. 1988. Pagurus bernhardus (L.) — an introduction to the natural history of hermit crabs. Field Studies, 7: 189 - 238.

Limaverde, A.M.; Wagener, A.L.R.; Fernandez, M.A.; Scofield, A.L. and Coutinho, R. 2007. Stramonita haemastoma as a bioindicator for organotin contamination in coastal environments. Marine Environmental Research, 64: 384-398.

Litulo, C. 2005. Population structure and reproduction of the hermit crab Dardanus deformis (Anomura: Diogenidae) in the Indian Ocean. Journal of the Marine Biological Association of the United Kingdom, 85(4): 883-887.

Lively, C.M. 1988. A graphical model for shell-species selection by hermit crabs. Ecology, 69: 1233-1238.

Mantelatto, F.L. and Dominciano, L.C.C., 2002. Pattern of shell utilization by the hermit crab Paguristes tortugae (Diogenidae) from Anchieta Island, southern Brazil. Scientia Marina, 66(3): 265272.

Mantelatto, F.L. and Garcia, R.B. 1999. Reproductive potential of the hermit crab Calcinus tibicen (Anomura) from Ubatuba, São Paulo, Brazil. Journal of Crustacean Biology, 19(2): 268-275.

Mantelatto, F.L. and Garcia, R.B. 2000. Shell utilization pattern of the hermit crab Calcinus tibicen (Diogenidae) from southern Brazil. Journal of Crustacean Biology, 20(3): 460-467.

Mantelatto, F.L. and Martinelli, J.M. 2001. Relative growth and sexual dimorphism of the South Atlantic hermit crab Loxopagurus loxochelis (Anomura, Diogenidae) from Ubatuba, Brazil. Journal of Natural History, 35(3): 429-437.

Mantelatto, F.L.; Alarcon, V.F. and Garcia, R.B., 2002. Egg production strategies of the tropical hermit crab Paguristes tortugae from Brazil. Journal of Crustacean Biology, 22(2): 390-397.

Mantelatto, F.L.; Martinelli, J.M. and Fransozo, A. 2004. Temporal-spatial distribution of the hermit crab Loxopagurus loxochelis (Decapoda, Anomura, Diogenidae) from Ubatuba Bay, São Paulo State, Brazil. Revista de Biologia Tropical, 52(1): 47-55.

Mardia, K.V. 1970. Measures of multivariate skewness and kurtosis with applications. Biometrika, 57: 519530.

Mardia, K.V. 1980. Tests of univariate and multivariate normality. p. 279-320. In: P.R. Krishnaiah (ed.), Vol. 1. Handbook of Statistics.

Markham, J.C. 1968. Notes on the growth-patterns and shell-utilization of the hermit crab Pagurus bernhardus (L.). Ophelia, 5: 189-205.

Martinelli, J.M. and Mantelatto, F.L. 1999. Shell utilization by the hermit crab Loxopagurus loxochelis (Diogenidae) in the Ubatuba Bay, Brazil. p. 719731. In: F. R. Schram and J. C. Vaupel-Klein (eds.) Vol. 1. Crustaceans and the Biodiversity Crisis.

Martinelli, J.M.; Mantelatto, F.L. and Fransozo, A. 2002. Population structure and breeding season of the South Atlantic hermit crab, Loxopagurus loxochelis (Anomura, Diogenidae) from the Ubatuba 
region, Brazil. Crustaceana, 75(6): 791-802.

McLaughlin, P.A.; Komai, T; Lemaitre, R. and Rahayu, D.L. 2010. Annotated checklist of anomuran decapod crustaceans of the world (exclusive of the Kiwaoidea and families Chirostylidae and Galatheidae of the Galatheoidea) Part I Lithodoidea, Lomisoidea and Paguroidea. Raffles Bulletin of Zoology, 23: 5-107.

McLean, R.S. 1973. Direct shell acquisition by hermit crabs from gastropods. Experientia, 30: 20-208.

Melo, G.A.S. 1999. Manual de identificação dos Crustacea Decapoda do litoral brasileiro: Anomura, Thalassinidea, Palinuridea e Astacidea. São Paulo, Pleiade Editora, 551p.

Miranda, I.; Meireles, A.L.; Biagi, R. and Mantelatto, F.L. 2006. Is the abundance of the red brocade hermit crab Dardanus insignis (Decapoda: Anomura: Diogenidae) in the infralittoral region of southern Brazil determined by reproductive potential? Crustacean Research, 6 (Special Number): 45-55.

Negreiros-Fransozo, M.L.; Fransozo, A.; Mantelatto F.L.; Pinheiro, M.A.A. and Santos, S. 1997. Anomuran species (Crustacea, Decapoda) and their ecological distribution at Fortaleza bay sublittoral, Ubatuba, São Paulo, Brazil. Iheringia, Série Zoologia, 83: 187194.

Nenadic, O. and Greenacre, M. 2007. Correspondence analysis in R, with two- and three dimensional graphics: The ca package. Journal of Statistical Software, 20(3): 1-13.

Oksanen, J. 2011. Multivariate analysis of ecological communities in $\mathrm{R}$ : vegan tutorial. Available at http://vegan.r-forge.r-project.org/. Accessed on 09 September 2012).

Pinheiro, M.A.A.; Fransozo, A. and Negreiros-Fransozo, M.L. 1993. Seleçáo e relação com a concha em Isocheles sawayai Forest and Saint-Laurent, 1967 (Crustacea, Anomura, Diogenidae). Brazilian Archives of Biology and Technology, 36(4): 745-752.

R Development Core Team. 2009. R: A language and environment for statistical computing. R Foundation for Statistical Computing, Vienna, Austria. ISBN 3-900051-07-0. http://www.R-project.org.

Reese, E. 1968. Shell use, an adaptation for emigration from the sea by the coconut crab. Science, 161: 385386.

Reese, E.S. 1962. Shell selection behavior of hermit crabs. Animal Behavior, 10: 347-360.

Reese, E.S. 1963. The behavioral mechanisms underlying shell selection by hermit crabs. Behavior, 21: 78-126.

Reese, E.S. 1969. Behavioral adaptations of intertidal hermit crabs. American Zoologist, 9(2): 343-355.

Rios, E.C. 1994. Sea shells of Brazil. Fundação cidade do Rio Grande, Instituto Acqua, Museu Oceanográfico de Rio Grande, Universidade de Rio Grande. RS. 2a. Ed. V, 368p. + 113 pl.

Rittschoff, D. 1980. Chemical attraction of hermit crabs and other attendants to simulated gastropod predation sites. Journal of Chemical Ecology, 6: 103118.

Sanchez, G. and Trinchera, L. 2012. plspm: Partial Least Squares Data Analysis Methods. R package version 0.2-2. http://CRAN.R-project.org/package=plspm.

Torati, L.S. and Mantelatto, F.L. 2008. Uncommon mechanism of egg incubation in the endemic Southern hermit crab Loxopagurus loxochelis: how is this phenomenon related to egg production? Acta
Zoologica, 89: 79-85.

Vance, R.R. 1972. The role of shell adequacy in behavioral interactions involving hermit crabs. Ecology, 53(6): 1075-1083.

Wada, S. 2001. Reproductive characters and population structure of the hermit crab Pagurus ochotensis. Benthos Research, 56: 43-46.

Wada, S.; Sonoda, T. and Goshima, S. 1996. Temporal size covariation of mating pairs of the hermit crab Pagurus middendorffii (Decapoda: Anomura: Paguridae) during a single breeding season. Crustacean Research, 25: 158-164.

Wada, S.; Tanaka, K. and Goshima, S. 1999. Precopulatory mate guarding in the hermit crab, Pagurus middendorffi (Decapoda: Paguridae): effects of population parameters on male guarding duration. Journal of Experimental Marine Biology and Ecology, 239: 289-298.

Wold, S. 1995. PLS for multivariate linear modeling. p. 195-218. In: H. van de Waterbeemd (ed.), Chemometric Methods in Molecular Design. Methods and Principles in Medicinal Chemistry, Weinheim, Germany, Verlag-Chemie. Vol. 2

Zar, J.H. 1996. Biostatistical analysis. New Jersey: Prentice-Hall. 907p. 